\title{
Ecological consequences of Douglas fir (Pseudotsuga menziesii) cultivation in Europe
}

\section{Journal Article}

\section{Author(s):}

Schmid, Max; Pautasso, Marco; Holdenrieder, Ottmar

Publication date:

2014-01

Permanent link:

https://doi.org/10.3929/ethz-b-000079519

Rights / license:

In Copyright - Non-Commercial Use Permitted

Originally published in:

European Journal of Forest Research 133(1), https://doi.org/10.1007/s10342-013-0745-7 


\title{
Ecological consequences of Douglas fir (Pseudotsuga menziesii) cultivation in Europe
}

\author{
Max Schmid • Marco Pautasso • Ottmar Holdenrieder
}

Received: 8 July 2013/Revised: 22 August 2013/Accepted: 11 October 2013/Published online: 29 October 2013

(C) Springer-Verlag Berlin Heidelberg 2013

\begin{abstract}
Douglas fir (Pseudotsuga menziesii (Mirb.) Franco) was first introduced to Europe from North America more than 150 years ago, was then planted on a large scale and is now the economically most important exotic tree species in European forests. This literature review summarizes the current knowledge on the effects of Douglas fir on soil chemistry, plants, arthropods and fungi. Douglas fir shapes its abiotic environment similarly to native tree species such as Norway spruce, silver fir or European beech. In general, many organisms have been shown to be able to live together with Douglas fir and in some cases even benefit from its presence. Although the number of species of the ground vegetation and that of arthropod communities is similar to those of native conifer species, fungal diversity is reduced by Douglas fir. Special microclimatic conditions in the crown of Douglas fir can lead to reduced arthropod densities during winter with possible negative consequences for birds. The ecological impacts of Douglas fir are in general not as severe as those of other exotic tree species, e.g., Pinus spp. in South Africa and Ailanthus altissima, Prunus serotina and Robinia pseudoacacia in Europe. Nonetheless, Douglas fir can negatively impact single groups of organisms or species and is now regenerating itself naturally in Europe. Although Douglas
\end{abstract}

Communicated by C. Ammer.

M. Schmid $(\bowtie) \cdot$ M. Pautasso $\cdot$ O. Holdenrieder

Forest Pathology and Dendrology, Institute of Integrative

Biology (IBZ), ETH Zurich, 8092 Zurich, Switzerland

e-mail: mschmid@student.ethz.ch fir has not been the subject of large-scale outbreaks of pests in Europe so far, the further introduction of exotic organisms associated with Douglas fir in its native range could be more problematic than the introduction of Douglas fir itself.

Keywords Biodiversity - Co-introductions . Ecosystem services · Forest ecosystems · Invasion biology

\section{Introduction}

Human beings have shaped forest ecosystems in Central Europe since prehistoric times, thus reducing the extent of forests to gain space for agriculture, thereby changing tree communities by cultivating the most useful tree species (Engelmark et al. 2001; Carnus et al. 2006; Essl et al. 2011). One example is Norway spruce (Picea abies (L.) H. Karst.), which has been planted on a large scale due to its wood quality and fast growth, and is now one of the most important tree species for forestry in Central Europe. Norway spruce has thus reached a population size much bigger than natural processes would have allowed (Schlyter et al. 2006). But large-scale mortality due to wind throw and bark beetle infestations showed that forestry with Norway spruce, especially in pure stands, bears considerable risks and is not an adequate solution in the face of climate change (Zebisch 2005, p. 86). During the search for alternatives with lower risk and higher yield, foresters have grown non-native tree species from all over the world, including tree species that have then become problematic due to their invasive potential (in Europe, e.g., Ailanthus altissima, Prunus serotina and Robinia pseudoacacia). 
Fig. 1 Distribution map of Douglas fir in Europe with a resolution of $1 \times 1 \mathrm{~km}$, reprinted with permission from Brus et al. (2011)

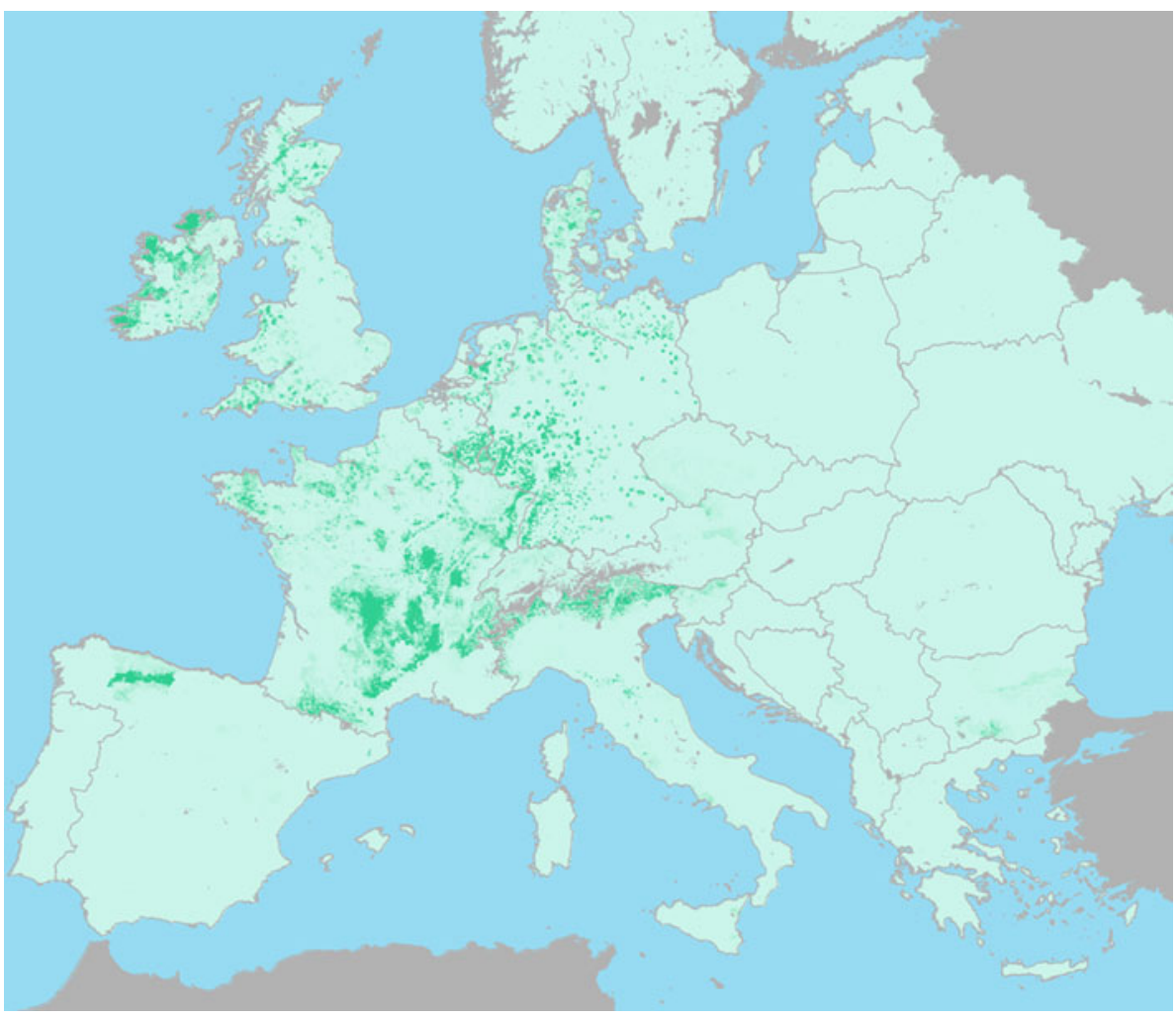

Today, the most abundant non-native tree species cultivated in Central European forests is Douglas fir (Pseudotsuga menziesii (Mirb.) Franco), which was first introduced in 1827 from western North America (Knoerzer and Reif 2002; Essl 2005). This conifer of the family Pinaceae is one of the eight existing species of Pseudotsuga according to Hermann (1982). The genus Pseudotsuga is thought to have originated in North America (with two currently existing species, $P$. macrocarpa and $P$. menziesii) and to have expanded into Eastern Asia through the Bering land bridge during the early Oligocene, currently with one species in Japan ( $P$. japonica) and Taiwan ( $P$. wilsoniana), and four species in mainland China ( $P$. brevifolia, $P$. forrestii, $P$. gaussenii and $P$. sinensis), although there is some debate about whether the Chinese species are really distinct (Wei et al. 2011). In its native range, P. menziesii covers a wide range of environmental conditions with a north-tosouth extension of $4,500 \mathrm{~km}$ (between $19^{\circ}$ and $55^{\circ} \mathrm{N}$ latitude) (Gugger et al. 2011; Wei et al. 2011). Douglas fir reaches maximum heights of over $100 \mathrm{~m}$ and yields of $28 \mathrm{~m}^{3} /($ ha*a) in managed forests (Russell et al. 1990). In contrast to the inland variety $P$. menziesii ssp. glauca, the coastal variety $P$. menziesii ssp. menziesii was found to be exceptionally suitable for European forests. High growth rates as well as rapid wound closure, good wood properties, resistance against the fungal pathogen Rhabdocline pseudotsugae Syd. and a low number of pests and diseases are factors that have contributed to the large present-day distribution of the coastal variety in European forests (Bußler and Blaschke 2004). Douglas fir was also supposed to be more resistant to wind throw than Norway spruce, but a study from Southwest Germany suggests that the two species are equally vulnerable to storm damage under current management conditions (Albrecht et al. 2013). However, storm susceptibility could be lower in case of a more complex forest structure (Schütz and Pommerening 2013). In 2008, Douglas fir acreage covered approximately $3 \%$ of the total ideal forest area in France $(427,000$ ha), $2 \%$ of the total ideal forest area in Germany (241,000 ha) and additional areas in the Netherlands (16,000 ha), Poland (4,852 ha), Austria (1,000 ha), Denmark (5,690 ha), Switzerland (2,540 ha) (Kownatzki et al. 2011), the British Isles (45,000 ha) (Smith and Gilbert 2003) and Sweden (Felton et al. 2013) (see also Fig. 1). In the future, the area of forests with the presence of Douglas fir in Europe is expected to increase further and, at least in Germany, Douglas fir is likely to become the third most important conifer in forests after Norway spruce and Scots pine (Pinus sylvestris L.) (Höltermann et al. 2008).

From an ecological point of view, cultivation of Douglas fir in Europe is likely to have significant impacts on forest ecosystems (Essex and Williams 1992; Peterken 2001; Felton et al. 2013), particularly in case of stands of pure Douglas fir and with high density of this species over large areas. Douglas fir plantations are particularly deleterious from a nature conservation point of view when they replace 
species-rich and threatened ecosystems such as forest glades and heathlands (Fagúndez 2013). The introduction of Douglas fir can also be considered as a replicated largescale experiment in the assembly of novel ecosystems (Seastedt et al. 2008; Hobbs et al. 2009; Pearse and Altermatt 2013), which could become important if assisted migration (the artificial translocation of plant species to enable them to cope with rapid climate change) will be adopted as a conservation strategy (Iverson and McKenzie 2013; Schwartz and Martin 2013). Several cases in the past have shown that exotic and invasive organisms can alter ecosystems, landscapes and ecosystem services (Knight et al. 2001; Richardson and Rejmánek 2004; Benesperi et al. 2012; Dodet and Collet 2012). In the United States, invasive exotic species cause costs of about $\$ 120$ billion per year (Pimentel et al. 2000, 2005). Globally, exotic species are considered one of the main reasons for the loss of biodiversity (IUCN 2000). The Pinus species introduced to South Africa show that trees are no exception to such threat. Beside economic and aesthetic benefits, the replacement of grass- and shrublands by pine forests reduced the freshwater run-off, increased the intensity of fires as well as the loss of soil due to subsequent erosion. Finally, the introduction of exotic pines reduced the population of 90 bird species of which half are endemic (van Wilgen and Richardson 2012). Tree species should therefore be introduced into new areas with caution and together with research to detect and prevent deleterious consequences.

Although over 150 years have passed since Douglas fir was introduced in Europe and although its cultivation has been intensified during the past century, there is still the lack of a comprehensive compilation of valuable studies about the ecological impacts of Douglas fir in Central Europe. This review aims thus to summarize and discuss the current knowledge regarding effects of Douglas fir on soil chemistry, plants, arthropods, as well as fungi. The literature was searched systematically at the end of 2012 using as keywords "Douglas fir", "Pseudotsuga menziesii", "Douglasie", "sapin de Douglas", "Douglasia" and "abete di Douglas" and as search tools "Web of Science" and "Google Scholar". Since several studies on this topic were published in languages other than English (see Meyer 2011; Budde 2006; Knoerzer 1999; Utschik 2006), the review also aims to make this literature accessible beyond linguistic borders. Because there has been little attention to the effects of Douglas fir on vertebrates in Europe, this issue is not considered here (but deserves research; Kolb 1996). Only deer browsing and buck rubbing has been reported occasionally and the impact is similar or higher on Douglas fir compared to Norway spruce (Wezel 2008; Metzler 2010; Kownatzki et al. 2011).

\section{Effects on soil chemistry}

Soil chemistry is shaped by the canopy-forming tree community. For instance, litter fall and root exudates link the tree with other organisms connected with the soil, including arthropods, the ground vegetation and microorganisms (Binkley and Giardina 1998). In the following, the impact of the introduction of Douglas fir on soil chemical characteristics is summarized to evaluate the impact of this foreign tree species on soil biota and nutrient cycling.

Prietzel and Bachmann (2012) studied 18 sites with former plantations of Norway spruce (16 sites) and Scots pine ( 2 sites) which had been transformed into Douglas fir and European beech (Fagus sylvatica L.) stands between 33 and 123 years ago. The study areas cover a wide range of environmental conditions and are expected to be representative of forest sites in Central Europe (Prietzel and Bachmann 2012). Humus form, soil organic carbon (concentration and stock), $\mathrm{C} / \mathrm{N}$ ratio and nitrogen (concentration and stock) showed significant differences among different stand types. Specifically, the replacement of Norway spruce and Scots pine by Douglas fir and European beech led to $\mathrm{C} / \mathrm{N}, \mathrm{OC}$ and $\mathrm{N}$ stock decreased within the organic litter. However, concerning the other layers (topsoil $0-10 \mathrm{~cm}$, and subsoil $10-30,30-50$ and $50-80 \mathrm{~cm}$ ), a less uniform picture was detected. Such a non-unidirectional impact of Douglas fir was also shown on forest soil chemistry (Malchair and Carnol (2009) and on the rhizosphere chemistry (Calvaruso et al. 2011; Mareschal et al. 2010; Turpault et al. 2005, 2007). This complexity is not surprising, considering that tree species is only one factor out of many that influence forest soil chemistry, from bed rock to climate conditions, ground vegetation or stand history (Ganssen 1972). Unless more time is needed to perceive the effects of Douglas fir on the lower soil horizons, it appears that Douglas fir is not creating chemical soil properties completely divergent from those observed with native Central European tree species (Augusto et al. 2002, 2003).

Nonetheless, Douglas fir maintains a high fine root density from the surface to a depth of $23 \mathrm{~cm}$, whereas fine roots of oak (Quercus petraea (Matt.) Liebl.), Norway spruce and European beech concentrate in the topmost soil layer (Calvaruso et al. 2011). High fine root densities in deeper soil layers might help reduce interspecific competition for nutrients with other tree or shrub species and can be interpreted as niche separation. Such a vertical differentiation of the fine root system has been shown for Douglas fir in mixed stands with Norway spruce (Lei et al. 2012) and also in mixed Douglas fir-European beech stands (Hendriks and Bianchi 1995).

To summarize this section, the indirect effects of Douglas fir on soil chemistry seem to be similar to those of 
native tree species and might allow coexistence with the organisms living on and in the soil. This hypothesis needs to be further tested in a wider variety of regions and soil conditions, e.g., at metal-polluted sites (Van Nevel et al. 2013), and with long-term monitoring of soil functions, e.g., nitrification rates (Mareschal et al. 2013) and $\mathrm{N}$ retranslocations (Wang et al. 2013). Moreover, the general assumption that Douglas fir is harmless from the point of view of soil conditions disregards more specific interactions at the molecular level, e.g., allelopathy, which could have an impact on soil organisms even if the general chemical soil properties are suitable for them (Steinlein 2013; Prescott and Grayston 2013).

\section{Effects on plants}

\section{Species diversity of plants}

Budde (2006) compared the understory vegetation of at least 50 years old pure (European beech, Scots pine and Douglas fir) and mixed forest stands (Douglas fir-Norway spruce, Scots pine-European beech, Douglas fir-European beech) in the course of the growing season 2003. The study sites were located in the north-western lowlands of Germany with mainly oceanic climate (mean annual precipitation $650-800 \mathrm{~mm}$, mean annual temperatures 8.4-8.9 ${ }^{\circ} \mathrm{C}$ ) and soils classified as secondary podzols. In this study, no plant or moss species was exclusively present in a single-stand type, although preferences were detected. In terms of the species diversity of plants and mosses in the underlayer and ground cover, Douglas fir and Douglas firNorway spruce stands displayed the highest species numbers whereas pure European beech and mixed European beech-Scots pine stands exhibited the lowest species numbers. A similar pattern was identified by Augusto et al. (2003) when they studied the impact of six tree species on vegetation and soil properties at 26 locations within the northern half of France. Although a reduced vegetation cover within Douglas fir stands was detected for some comparisons, these authors found no reduction in species richness, but even an increase when Douglas fir stands were compared to European beech stands. This pattern could be caused by differences in the light supply, which was severely reduced in European beech stands over summer compared to Douglas fir and Norway spruce stands (Budde 2006). The low light supply in European beech stands impeded plant growth in the understory and allowed only a small number of species to grow. Concerning the functional species groups (dispersal strategies, life forms after Raunkiær and preferred ecosystems, e.g., open land inhabitants), no pattern was detected separating the ground vegetation in Douglas fir stands from that in native tree species stands. In general, the results suggest that pure and mixed Douglas fir stands can host a diverse understory vegetation, which, in species number and composition, is not much different from the understory vegetation in native conifer stands. The differences in species diversity are expected not to be the result of the canopy-forming tree species alone but of different light conditions, which are mainly shaped by stand age, stand composition and stand structure. Therefore, contrasts in species diversity arise rather between pure conifer and pure broadleaf stands than among species of the same group (Budde 2006).

At two different locations in western Bavaria in Germany, Leitl (2001) compared the vegetation in a pure Douglas fir stand with two pure stands of Norway spruce and European beech as well as mixed stands of two forest reserves with the presence of Norway spruce-European beech and oak (Quercus robur L.)-European beech. Surprisingly, the forest reserves exhibited the lowest and the two Norway spruce and the Douglas fir stands exhibited the highest species diversity. The high diversity of ground vegetation in the Norway spruce stand could be due to the co-occurrence of still present relict species typical of European beech stands. Other explanatory factors include the species characteristics of Norway spruce stands and their higher spatial heterogeneity due to wind throw gaps and skidder trails. The high diversity in the Douglas fir stand is a consequence of the infiltration of ruderal species from a forestry road and skidder trails. One further remarkable observation is the epiphytic growth of an undetermined fern on Douglas fir stems up to a height of $10 \mathrm{~m}$, which was enabled by the coarse bark structure of Douglas fir.

Are the reported effects of Douglas fir on plant diversity the result of its function as a physical ecosystem engineer? Physical ecosystem engineers control the availability of resources for other organisms (Jones et al. 1997). In particular, the impact of tree species on the light supply in the understory is important for the understory vegetation (Barbier et al. 2008). Nonetheless, there is no competition for light between a mature tree and the understory vegetation but rather a top-down regulation of this resource. Douglas fir appears to influence the light regime similarly to the effect of native tree species. Analogously to soil chemistry, the overall soil, light, water and probably temperature conditions in Douglas fir stands are not much different from those of native tree species (Voloscuk 2012). Therefore, relatively many plant species manage to live in pure and mixed stands of Douglas fir. However, differences in species composition have been documented, with species of the natural forest community rarely present in Douglas fir stands (Leitl 2001). Consequently, the species number alone is not a sufficient indicator of near-natural conditions, and species composition should be taken into 
account in future studies of the ecological impacts of Douglas fir on plant diversity. This situation of a different community composition despite similar abiotic conditions might be the result of allelopathic interactions causing the absence of some plant species (Chou 1993; Rice 1979). Secondary plant compounds of Douglas fir tissues were analysed several times (e.g. Kuiters and Sarink 1986; Dellus et al. 1997; Oh et al. 1967; Zou and Cates 1995), but the few available studies including effects on vegetation focused rather on allelopathic inhibition of Douglas fir seedlings by other plant species than vice versa (Del Moral and Cates 1971; Rose et al. 1983; Tinnin and Kirkpatrick 1985).

The two studies of Budde (2006) and Leitl (2001) furthermore showed some problems faced by research on the ecological impacts of exotic tree species. It is difficult to uncouple the effect of a single tree species on its environment from the effect of other factors such as stand age, history and structure, as well as temporal variations between seasons and years. Most studies of ecological effects of Douglas fir are to be taken with caution due to such confounding factors. Moreover, it is not easy to set the standard for comparisons. In many parts of Europe, Douglas fir is used as an alternative to its nearest relative in Europe (Norway spruce) and a comparison seems to be reasonable (Goßner 2008). But in many European forest sites, Norway spruce has been grown outside of its natural range and is not part of the assumed natural tree species community. Thus, the conservation potential of a change from conifers to forestry with autochthonous deciduous tree species is disregarded when Douglas fir is only compared with Norway spruce (Bürger-Arndt 2000). A way out of this impasse would be a comparison of Douglas fir's impacts on biota in pure and mixed conifer as well as broadleaved stands as it has been implemented in several studies.

\section{Natural regeneration}

The natural regeneration of Douglas fir in Europe is not a local and recent phenomenon: it has already been reported from Austria, Bulgaria, France, Germany, Switzerland, the UK (Knoerzer 1999), Italy (Avolio and Bernardini 2000) and the Czech Republic (Bušina 2007) since the 1950s, as well as outside of Europe in Argentina, Chile and New Zealand (OECD 2008). Recently, natural regeneration of Douglas fir was reported in Mediterranean mountain forests in Spain (Broncano et al. 2005; Carrillo-Gavilán et al. 2012). The ability to regenerate naturally is important because it provides the possibility for Douglas fir to increase its local abundance and regional distribution in Europe, thereby changing the tree species composition independently and multiplying the ecological impacts of this tree species. Knoerzer (1999) determined the natural regeneration of Douglas fir in the Black Forest in Germany as representative for the soil acid mid-range mountains in Central Europe. In this dissertation, the author detected natural regeneration of Douglas fir in a large set of locations and stand types in the Black Forest in Germany. Douglas fir seedlings were able to establish among and compete successfully with other common tree species such as silver fir (Abies alba Mill.), European beech and Norway spruce, especially on sites with acid soils and a good light supply. In Bavaria, Douglas fir occurs in 27 out of 160 forest reserves, but natural regeneration within closed forests was rarely observed (Endres and Förster 2013). These results imply that Douglas fir is no longer dependent on human plantings but can now regenerate independently and establish successfully in neighbouring stands. In Germany and neighbouring countries, natural regeneration of Douglas fir has become a matter of debate in nature conservation (Kaiser and Purps 1991; Walter et al. 2005; Zerbe 2007; Fischer 2008; Walentowski 2008; Meyer 2011; Konnert and Fussi 2012). To maintain the Q. petraea (Mattuschka) Liebl. stands on acidic soil with their high number of rare and endangered species, natural regeneration of Douglas fir has to be removed regularly (Knoerzer 1999). Conversely, a study from the Netherlands reported spontaneous regeneration of native tree species in monotonous conifer plantations, including those of Douglas fir (Jonášová et al. 2006). Regeneration of Douglas fir depends also on the resident soil microbial community (Haugo et al. 2013) and co-introductions of suitable mycorrhizal fungi can enhance its invasiveness (Dickie et al. 2010). Although Douglas fir stands seem to create conditions similar to those created by native conifers (as seen in "Effects on plants" and "Arthropod species diversity" sections), this exotic tree could change habitats distinctly, given that Douglas fir invades deciduous tree stands (Fischer 2008). Further research is needed on whether the ecological impacts (or lack thereof) of Douglas fir plantations are similar to those of Douglas fir stands established naturally.

\section{Effects on arthropods}

Arthropod species diversity

In Europe, at least 87 phytophagous insect species have been recruited by Douglas fir, which is about one-third of the number of species observed on this tree species in its native North American range (Goßner and Bräu 2004; Roques et al. 2006). Many of these recruited species are polyphagous (42\%) and feed on more than one plant family. The relative high proportion of monophagous insects (30\%) on Douglas fir may be based on the definition of monophagous, which here includes species feeding or fulfilling their larval stage 
within a single plant genus. But this number seems to indicate that the chemical or mechanical defence system of Douglas fir allows even several specialized species to cope with it. This has been attributed to the taxonomic closeness of Douglas fir to native tree species (the closest relative in Europe is Norway spruce) as well as to the generally low diversity of secondary plant compounds of gymnosperms (Tahvanainen and Niemelä 1987). This argument is supported by the observation of Roques et al. (2006) that all monophagous arthropods recruited by Douglas fir in Europe have conifers (mainly Norway spruce) as primary hosts and by the observation of phylogenetic conservatism in the assembly of the phytophagous fauna on Douglas fir in Bavaria (Goßner et al. 2009). The results of Goßner and Simon (2002) support these assumptions as their survey detected no difference in the species number as well as only slight differences in the community structure of crowndwelling beetles between six Norway spruce and Douglas fir trees, respectively. Concerning the relative proportion of species in each insect order as well as the guild structure, arthropod communities on Douglas fir do not differ significantly between Europe and North America (Roques et al. 2006). Although there are some insect families which have not yet been found feeding on Douglas fir in Europe in contrast to North America and vice versa, recruitment has taken place on a broad taxonomic and functional scale (Roques et al. 2006).

Arthropods and the physical environment provided by Douglas fir

A large part of Douglas fir's impact on the biota in a forest ecosystem can be ascribed to its function as a physical ecosystem engineer (Jones et al. 1997). In the following section, the resulting impacts of the physical influences of Douglas fir trees on arthropod communities are compared with those of native trees.

Ziesche and Roth (2008) studied the distribution of soildwelling spiders of two pure stands (Norway spruce and Douglas fir) and two mixed stands (European beech-Norway spruce, Oak ( $Q$. robur)-European beech) within four age classes between 15 and 112 years at a small spatial scale (10 $\mathrm{m}$ distance between pitfall traps). Correlations were tested with canopy-forming tree species and habitat parameters such as temperature, air humidity, soil characteristics and vegetation features. It was shown that many spider species were not randomly distributed and especially the Douglas fir and mixed oak-European beech stands possessed some specific spider assemblages. Concerning the link between the canopy-forming tree species and the spider assemblage, a seasonal pattern was observed. In spring, there was a distinct difference in species composition between the conifer and deciduous tree stands. This can be explained by the different abiotic conditions between conifer and deciduous tree stands in this season of the year. In the course of the growing season, the environmental parameters in conifer and broadleaved stands became more similar to each other and the spider assemblage was not clearly correlated with tree species in summer and fall. The most important parameters for the prediction of the species distribution were litter type, canopy closure, temperature, grass and moss cover as well as soil moisture. This suggests that the ecological impact of Douglas fir as physical ecosystem engineer changes with season and stand age and is to a large extent dependent on forest management.

Goßner and Ammer (2006) studied the tree-specific arthropod communities of Douglas fir and Norway spruce in three stand types (Norway spruce, European beech and Douglas fir) in two study sites in Bavaria (Germany) over three consecutive vegetation periods (March-October) on the stem as well as in the crown. In the stem, Douglas fir revealed lower species diversity compared to Norway spruce (in European beech-dominated and Norway spruce-dominated stand types). This is assumed to be the result of a different bark structure of Douglas fir representing a less suitable pathway for stratum changing arthropods than the less structured bark of Norway spruce (Goßner and Ammer 2006). Differences in bark might explain the low species numbers detected on Douglas fir in the studies of Glatz et al. (2003), Winter (2001), Winter et al. (2001) and Kohlert and Roth (2000). This special, less suitable bark structure was also assumed to have an effect on arthropods in the crown. If the colonization of Douglas fir crowns over the stem is constrained for some arthropod species, colonization from neighbouring trees becomes necessary and the general stand composition and structure gain in importance. Goßner and Ammer (2006) assumed that the higher Norway spruce to Douglas fir distance in European beech-dominated stand types was the reason for the relatively low arthropod species number in Douglas fir crowns compared to that of Norway spruce in this stand type. In general, the diversity of arthropod communities in the tree crown of Douglas fir was significantly higher (in Douglas fir- and Norway sprucedominated stand types) or the same (in European beechdominated stand types) as compared to Norway spruce, but fluctuated strongly with years and observed guild. Goßner and Ammer (2006) assumed that Douglas fir and Norway spruce crowns differ in their microclimatic conditions, which are the result of (1) Douglas fir's higher canopies [the species already reaches heights over $50 \mathrm{~m}$ in Europe; Kownatzki et al. (2011)], (2) horizontal and not pendulating twigs and thus (3) a more open structure. These factors probably lead to warmer conditions in the Douglas fir crown during summer and support the additional establishment of thermophilous species. In contrast to summer time, Goßner and Utschik (2002) showed for the same study site that in 
winter 2000 and February 2001 almost no arthropods (on two examined trees) and no foraging birds (in a 6.25 ha large area) could be found on Douglas fir crowns. This might be the result of unfavourable microclimatic conditions during winter in the crown of this tree species.

These results show that Douglas fir can possess special abiotic habitat conditions compared to Norway spruce as a result of divergent bark and crown structures, thus exhibiting different arthropod communities. Although these differences were observed only during a short period of the year and affect only specific groups of organisms, cascading effects on lower or higher trophic levels can be expected and should be the object of further research.

Douglas fir as food resource for arthropods

The chemical composition of wood, bark and needles is crucial for herbivorous and decomposing arthropods. Secondary plant compounds are thought to act as a chemical defence against consumption by herbivores and decay by decomposers (Horner et al. 1988; Haslam 1994; Schowalter et al. 1986).

The decomposer communities of European beech, Norway spruce and Douglas fir were compared at two sites in Bavaria (Engel 2001). While European beech stands were characterized by high individual numbers concerning the macro-fauna (Isopoda, Diplopoda and Lumbricidae), Norway spruce was rather dominated by the meso-fauna (Collembola, Acari and Nematoda). Douglas fir was in an intermediate position between these two tree species. However, the study gives no information on species numbers, guild structure or temporal patterns. The litter decay rate of Douglas fir was similar to that of the native conifers Norway spruce, silver fir and European larch and was thus rather slow compared with native broad leaved species such as common hornbeam (Carpinus betulus L.) or sycamore maple (Acer pseudoplatanus L.). Unless the result is due to differences in site conditions, this finding would suggest that the secondary plant compounds of Douglas fir are similar to those of the studied native conifers, thus allowing detritivores to use Douglas fir needles as food source. There are also reports of higher quality of the leaf litter (and thus higher biomass of detritivores) for Douglas fir compared to Norway spruce, because, contrary to Douglas fir, the needles of $P$. abies cause acidification of the litter (Pontégnie et al. 2005).

This palatability of the secondary plant compounds is not only acknowledged by the severe damages arising from the large pine weevil Hylobius abietis (Linnaeus, 1758) (Wallertz and Malmqvist 2013), but is also supported by the colonization of Douglas fir by several bark beetle species. Bertheau et al. (2009) reported eight indigenous bark beetle species, Laufhütte (1997) detected 24 species on Douglas fir in Europe, and Bringmann (2001) reported 14 bark beetle species which used Douglas fir for their larval stage (as reported in Goßner 2004). But in contrast to the native tree species, Douglas fir in Europe has so far not been the subject of large-scale outbreaks of an insect herbivore. After the cyclone "Lothar" in December 1999, only $2.6 \%$ of the Douglas fir trees surveyed in France had been attacked by bark beetles in autumn 2000 (versus $36 \%$ of Norway spruce) and only $6 \%$ by autumn 2001 (versus $72 \%$ of Norway spruce) (Roques et al. 2006). Although bark beetles can breed more or less successfully on Douglas fir, some chemical properties of Douglas fir seem to constrain their fitness.

Gruppe and Goßner (2006) studied the eating habits of black arches larvae (Lymantria monacha (Linnaeus, 1758)), a polyphagous palearctic lepidopteran, providing the caterpillars a choice between Norway spruce and Douglas fir needles. The test showed that black arches prefer Douglas fir needles compared to Norway spruce needles. The authors argued that high contents of fructose and glucose could act as feeding-stimuli favouring Douglas fir consumption. But the consumption of Douglas fir needles led to reduced larval weights which might be caused by high concentrations of organic acids (quinic and shikimic acid) and procyanids increasing the energy demand for metabolizing Douglas fir needles and thus hindering carbon assimilation. In contrast to black arches, larvae of the great spruce bark beetle (Dendroctonus micans Kugel.) feeding on Douglas fir bark had the lowest survival rate compared to individuals feeding on four further conifer species' bark (Japanese larch (Larix kaempferi Sarg.), grand fir (Abies grandis (Dougl.) Lindl.), Norway spruce and Serbian spruce (Picea omorika (Panc.) Purk.), and a successful completion of the lifecycle of the bark beetle is unlikely (Wainhouse and Beech-Garwood 1994).

On the whole, the chemical composition of Douglas fir tissues seems to be similar to the one of Norway spruce. This comparability might be the result of the taxonomic closeness and a low degree of specialisation in conifer insect herbivores (Roques et al. 2006; Tahvanainen and Niemelä 1987; Goßner 2004). However, there seems to be some distinct incompatibilities, as even polyphagous herbivores such as black arches cannot cope well with this diet. A detailed chemical analysis would be necessary to clarify this inference.

Co-introduced exotic arthropods on Douglas fir in Europe

From their native habitat in western North America, three parasites followed Douglas fir to Europe, namely the Douglas fir woolly aphid Gilletteella (Adelges) cooleyi as well as Giletteella coweni and the seed cone wasp Megastigmus spermotrophus (Goßner 2004). In the following, 
ecological impacts caused by these co-introduced insect species from the native range are listed.

Goßner et al. (2005) compared the aphidophagous insect community of Douglas fir and Norway spruce in Douglas fir-, European beech- and Norway spruce-dominated stand types in south-western Bavaria (Germany) from March to October 2000, using flight interception traps. Although no measurements were conducted, the authors assumed that the aphidophagous insect community on Douglas fir relies almost solely on Douglas fir woolly aphid because native aphids have not been reported to reach higher densities on Douglas fir. The aphidophagous insect community on Douglas fir exhibited significantly higher numbers in specimens and species compared to Norway spruce in all stand types. This indicates that a broad range of aphidophagous insects, including species with different demands and degrees of specializations, have the ability to use this exotic species at least as secondary food resource, even profiting from it and thus increasing their population sizes. For forestry, a beneficial effect can be expected when the antagonists of aphids are supported to increase their population size, thereby exerting a stronger control of the aphid communities on indigenous trees. But not all insects feeding on aphids are able to use this new resource. Goßner mentioned in his dissertation that in the book of Gösswald (1990), ants are reported to refuse Douglas fir woolly aphids and decrease in their abundance in Douglas fir stands.

Auger-Rozenberg and Roques (2012) sampled seeds from Douglas fir in seed orchards in south-western France over almost two decades to survey the population of Megastimus spermotrophus, a seed chalcid introduced to Europe at the end of the nineteenth century. They reported a wide distribution, abundance and impact of $M$. spermotrophus in and on Douglas fir seeds. It can be assumed that this exotic insect occupied the whole niche of cone and seed insects because of missing competitors until the arrival of exotic seed bugs (Leptoglossus sp.) in 2008. Although no switch to native tree species has been reported for M. spermotrophus, such a host jump has been reported for Megastimus schimitscheki in France (AugerRozenberg and Roques 2012). It is possible that other organisms introduced from western North America or other regions could make this step and cause widespread ecologic and economic problems in the future (Kirichenko et al. 2013).

\section{Effects on fungi}

Fungal diversity associated with Douglas fir

Vacher et al. (2010) reported in their meta-analysis that the introduction status (exotic or native) of tree species growing in France has no significant effect on the number of interactions with fungal species and concluded that exotic species are well integrated into the French treefungus network. However, they believe that studies which quantify the interactions might show a different picture. This result is consistent with the study of Strong and Levin (1975), who detected a similar number of fungal species associated with introduced tree species in Britain compared to native ones, when the distribution area of the tree was taken into account. Therefore, a lower fungal species number of exotic trees would be rather a result of a small distribution area than of exotic tree-fungus incompatibilities. Strong and Levin (1975) also proposed that exotic tree species reach their limit in species richness of fungi rather rapidly due to the good dispersal ability of fungi.

In the fungal database of the United States Department of Agriculture (Farr and Rossman 2013), 59 fungal species are listed for Douglas fir in Europe, as opposed to 1,423 species in North America. This distinct difference in species numbers is surprising and seems to contradict the general assumptions of Vacher et al. (2010) outlined above. But the data from Farr and Rossman (2013) have to be interpreted with caution as the numbers of detected fungi species in Douglas fir stands from Utschik (2001) and Buée et al. (2011) are higher than 59 species. Nevertheless, regarding the fungal species number of the closest congener in Europe Norway spruce with 1,074 listed species in Europe, we can conclude neither that this database is just focusing on North America nor that Europe is poor in fungi. Confounding factors to be considered here are the 2.5 times larger area and the currently one-third smaller human population of North America compared to Europe, so that there are probably more observers in Europe than in North America for unit area. To obtain an overview and compare Douglas fir with other native and exotic tree species, we plotted the fungal diversity for the most common tree species of Europe against the area covered by the tree species in Central Europe (Fig. 2). For Douglas fir, this figure seems to contradict the assumption of Strong and Levin (1975) that introduced tree species have a similar number of associated fungal species compared to native tree species. Native fungi might be to a great extent incompatible with Douglas fir so that negative impacts on fungal diversity are likely to result from its cultivation. It is, however, possible that, since the focus of fungal research and observation has not been on exotic species so far, the real number of fungal species hosted by Douglas fir might be higher than reported. Indeed, other exotic trees such as $R$. pseudoacacia and Eucalyptus spp. exhibit relatively high species numbers of fungi in Europe (Fig. 2). 


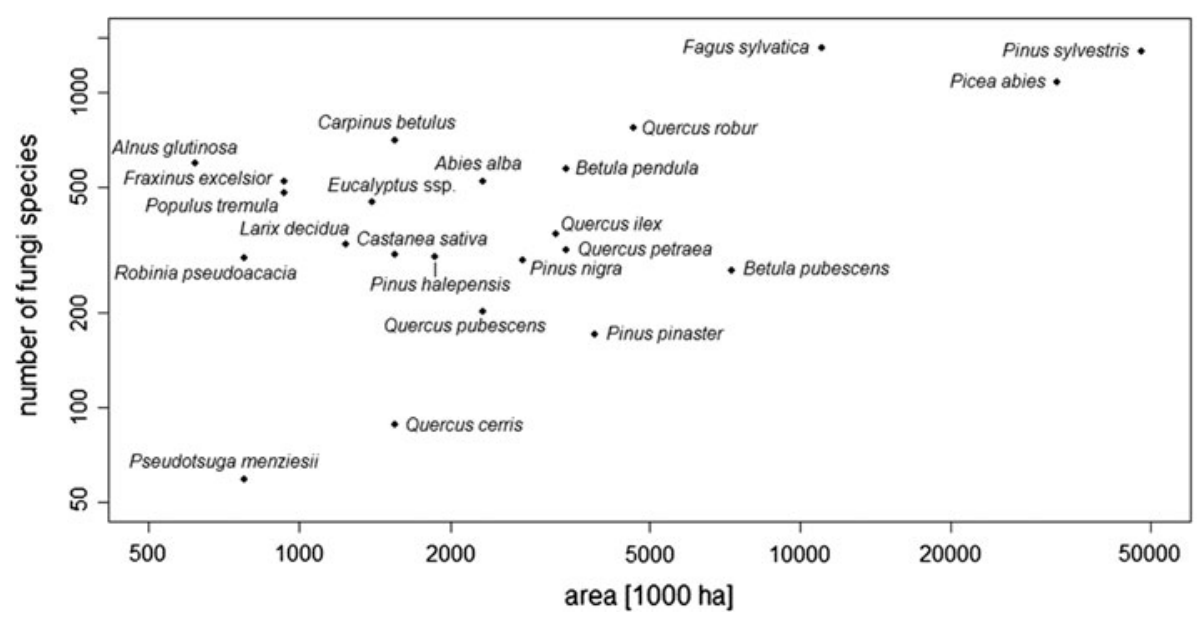

Fig. 2 Relationship between the area occupied by the most common tree species in Europe (Köble and Seufert 2001) and the number of fungi (Farr and Rossman 2013) associated with each tree species, including Douglas fir, in Europe plotted on logarithmic scales. The information on the total forest area of Europe derives from

Fungal diversity and temporal patterns

Parlade et al. (1995) studied the ability of 27 native fungi species from northern Spain to form ectomycorrhiza with Douglas fir seedlings in an artificial pure culture growth experiment to increase the fitness of Douglas fir seedlings after their out-planting. They found that 18 of the 27 species formed ectomycorrhiza with Douglas fir seedlings and eight of them colonized at least $50 \%$ of the fine roots. This indicates a relatively high capability of Douglas fir seedlings to cooperate with native fungi under aseptic conditions and supports the general expectations derived from Vacher et al. (2010) and Strong and Levin (1975), although the low-studied species number and the artificial growth conditions make extrapolation difficult.

In contrast, the study of Utschik (2001) shows a different pattern. In the years 1999 and 2000, fungal fruit bodies were sampled in five different stand types (Douglas fir-dominated, Norway spruce-dominated, Norway spruceEuropean beech mixed stands, deciduous trees and nature reserve) in old-growth forests in Bavaria and resulted in a total number of 429 detected fungi species out of 3,307 specimens. Pure Douglas fir stands exhibited the lowest total species richness of fungi compared to the other four stand types as well as the lowest number of endangered, rare and close-to-nature indicator fungi. The diversity and relative proportion of fungal guilds (mycorrhiza, saprotrophic fungi and others) matched most closely with that observed in Norway spruce. Saprotrophs together with mycorrhizal fungi were more abundant in conifer stands than wood decaying fungi, which dominated rather in deciduous tree stand types. The author concluded that pure
EuropeanCommission (2013). The regression of logarithmically transformed number of fungi against logarithmically transformed tree range area is significantly positive $(n=23, y=0.275+$ $0.360 x($ SE 0.127$), r^{2}=0.28, p=0.01$ )

Douglas fir stands should be avoided in forestry whereas an admixture to a European beech-dominated stand type has less severe ecological impacts.

A similar picture was revealed by Buée et al. (2011) when they studied the fungal diversity within $1,000 \mathrm{~m}^{2}$ large plantations of European beech, Oak (Q. petraea), Nordmann fir (Abies nordmanniana (Stev.) Spach), Norway spruce, Corsican pine (Pinus nigra J.F. Arnold) and Douglas fir. Over a study period of 7 years, they detected in total 331 fungal species, while Corsican pine and Douglas fir stands exhibited the lowest species numbers.

Jansen (1991) determined the fruit bodies of mycorrhiza in Douglas fir stands of three age classes $(<20$ years, 20-40 years, $>40$ years) over a large part of the Netherlands. She found decreasing species numbers and fruit body abundances of mycorrhizal fungi with increasing stand age, although no comparisons with other stand types were made. Such a pattern has already been observed in other regions on other tree species, e.g., in the study of Nordén and Paltto (2001) in hazel stands (Corylus avellana L.) in Sweden. As possible reasons, competitive exclusion or a more efficient recycling of nutrients of the tree were proposed. This result illustrates that temporal dynamics occur not only within or between years but also with proceeding succession over decades. Long-term studies or cross-sectional examinations to incorporate these dynamics are therefore necessary.

Co-introduced exotic fungi

As shown for arthropods in "Co-introduced exotic arthropods on Douglas fir in Europe" section, Douglas fir is not 
only affecting forest ecosystems by direct interactions with other biota but also indirectly through the co-introduction of exotic species associated with Douglas fir. Seedlings of Douglas fir (and, more in general, of conifers) in tree nurseries are frequently inoculated with fungi to increase the fitness after the out-planting (Dickie et al. 2010; Brodribb et al. 2012; Parlade et al. 1995). The dissemination and persistence of the American strain of Laccaria bicolor S238N used as inoculant were studied 10 years after the establishment of a Douglas fir plantation in France (Selosse et al. 2002). Although no selfing or introgression with indigenous strains was detected, the strain was still present a decade after its introduction. The possibility of indirect long-term ecological impacts of exotic trees by introductions of biota from the native range exists therefore not only for plants or arthropods but for fungi as well (Slippers et al. 2005). In general, the knowledge of tree-fungus interactions of Douglas fir in Europe is rudimental and demands further investigations.

This knowledge gap is particularly worrying in relation to (fungal) pathogens of Douglas fir. The host-specific needle parasites Phaeocryptopus gäumannii and $R$. pseudotsugae have already been introduced to Europe, South America and New Zealand (Watt et al. 2010; Morales et al. 2012). The increasing trade in plants for planting, bonsai, wood and other plant material poses a risk of inadvertent introduction of parasitic organisms currently unproblematic in the native range of Douglas fir (Ennos 2001; Augspurger 1984; Blaney and Kotanen 2001). Alternatively, but no less worryingly, globalization of trade could end up in introducing into Europe pathogens of Douglas fir originating from outside its native range, and thus potentially virulent due to the absence of co-evolution with the host (Fisher et al. 2012; Slippers et al. 2005; Loo 2009). For example, Phytophthora ramorum is an oomycete that has caused widespread tree (including Douglas fir) and shrub mortality in the west coast of the US, as well as in the British Isles, and which is likely to have been introduced to North America and Europe from Asia through the trade of ornamental plants for planting (Brasier and Webber 2010; Moslonka-Lefebvre et al. 2011; Moslonka-Lefebvre et al. 2009; Grünwald et al. 2012). Douglas fir is susceptible to this newly described pathogen (Garbelotto and Hayden 2012; Hansen et al. 2005; Davidson et al. 2002) and is thus at risk in Europe too, also given that $P$. ramorum has been frequently intercepted in the ornamental plant trade among EU countries (EFSA PLH 2011; Pautasso 2013; Prospero et al. 2013). Although introduced pathogens of Douglas fir may contribute in keeping this potentially invasive tree species under control and in producing deadwood, there is a risk that such pathogens may then jump to affect tree species native to Europe (Slippers et al. 2005). More research is needed on how to prevent the introduction of such pathogens into semi-natural forests in the presence of exotic tree species and on how to respond to disease outbreaks once exotic tree pathogens have become established.

\section{Conclusion}

Although relatively many studies have investigated the ecological effects of Douglas fir cultivation in Europe, several questions have not been answered yet or only insufficiently. For example, although it is clear that plantations of Douglas fir are susceptible to many root and butt rot fungi (Koch and Thomsen 2003; Ronnberg et al. 1999; Greig et al. 2001), little is known about the Douglas fir wood decay fungal community in Europe (Cornelissen et al. 2012; Deflorio et al. 2008). The available knowledge is sketchy, also because long-term experimental studies controlling for the many confounding factors in semi-natural and planted forests are rare (Rożen et al. 2010; Hobbie et al. 2006). The existing studies have been conducted in a small set of locations and may not be representative of the general situation in Europe. Only few studies compared silver fir with Douglas fir, although this native tree species is common in much of Central Europe and has abiotic demands similar to Douglas fir. Finally, the vast majority of the retrieved studies were conducted over 1 year, one growing season or across a single stand age only (Table 1). Such short-term studies fail to separate tree-related causes and relationships from temporal fluctuations, as the results of Jansen (1991), Budde (2006), and Goßner and Ammer (2006) show. Consequently, further investigations are necessary to confirm their results as well as the conjectures made in this review.

Despite the limitations of the available studies, what are the likely consequences of forest plantations of Douglas fir in Europe? The existing studies suggest that forest ecosystems in Central Europe are able to deal with the introduction of Douglas fir comparably well. Until now, no severe ecological or economic consequences have been detected, whereas large-scale attempts at eradicating Douglas fir from Europe would probably do more harm than good (Skurski et al. 2013). This is mainly because Douglas fir seems to shape the abiotic environment not that differently from native tree species. For example, species numbers of the ground-layer vegetation and of arthropod communities in soil, stem and crown were shown to be similar to those of Norway spruce (Budde 2006; Goßner et al. 2005; Leitl 2001; Ziesche and Roth 2008). But this is not always the case. When Douglas fir is able to invade native deciduous tree stands (in contrast to native conifers) or microclimatic conditions created by Douglas fir are considerably different in a specific time of the year, 


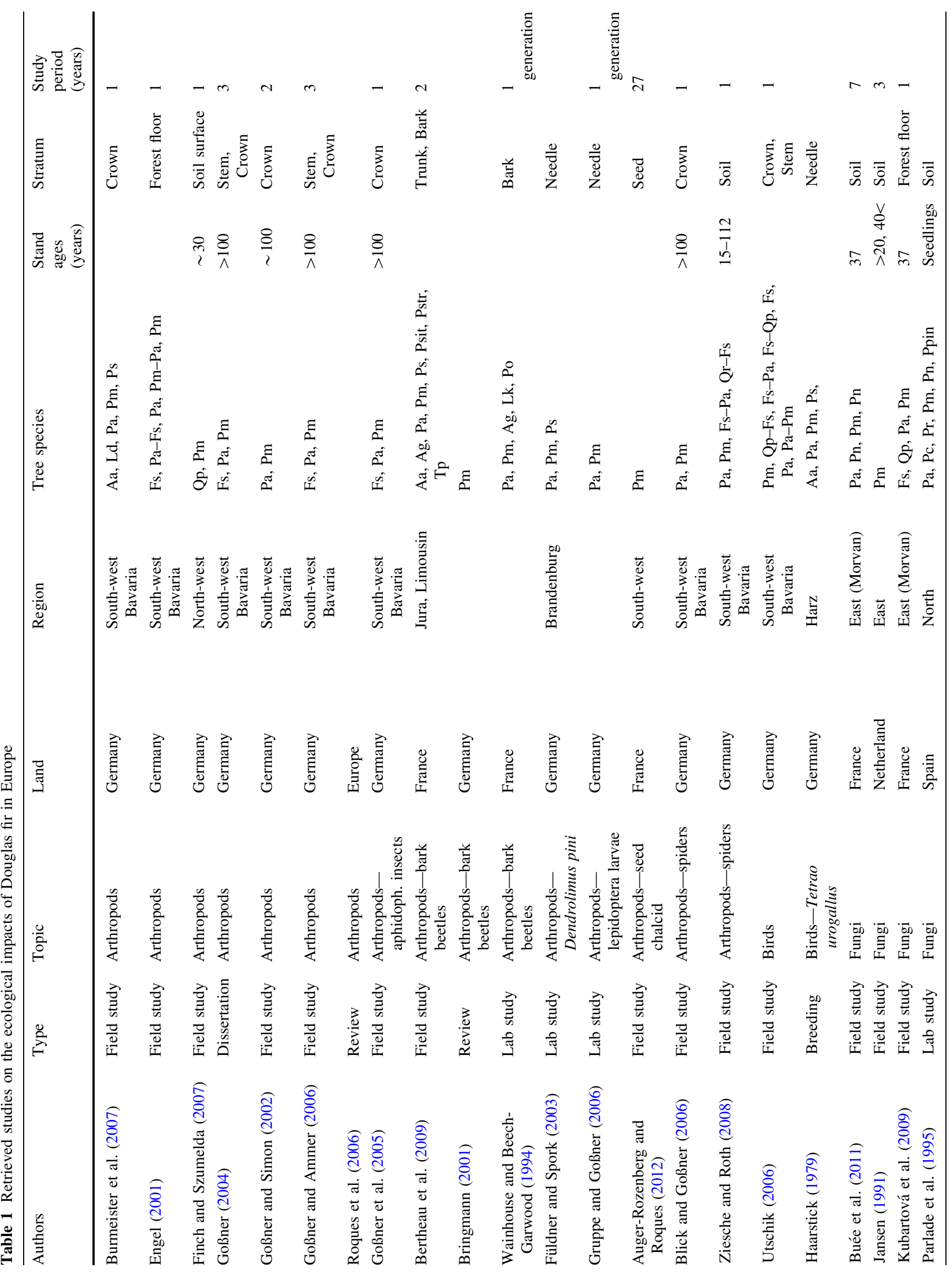




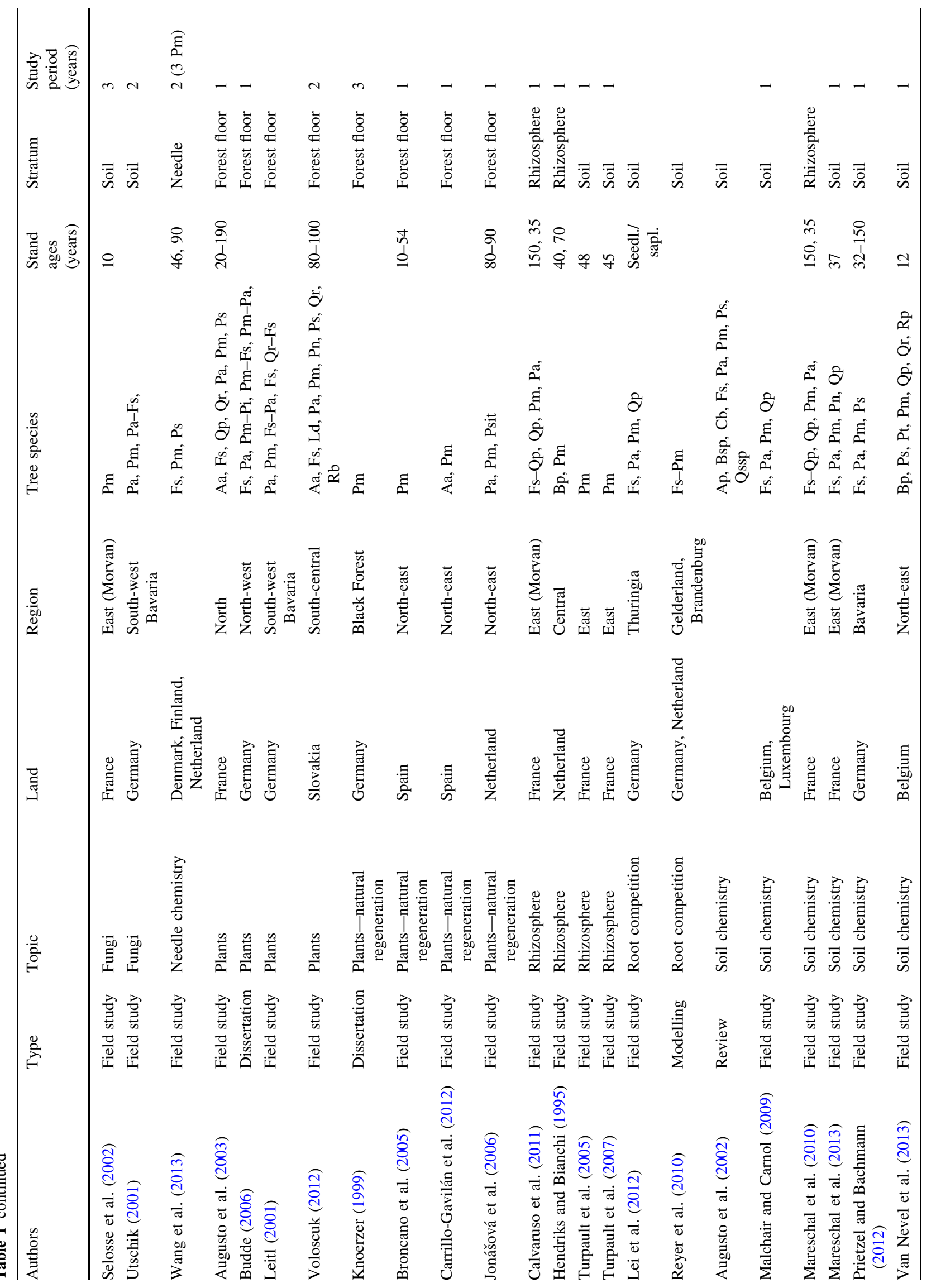


negative consequences for plants, arthropod and bird communities have been observed (Knoerzer 1999; Goßner and Utschik 2002). Similar negative effects are reported from a comparison of the vegetation and soil properties in Douglas fir plantations versus native Nothofagus forests in southern Chile (Frank and Finckh 1997). Larger differences to native tree species seem to exist at the molecular level in the chemical composition of plant tissues. This is supported by the observation that Douglas fir has not been victim of larger pest outbreaks in Europe so far (Roques et al. 2006). Moreover, Douglas fir hosts a low diversity of phytophagous arthropods (Roques et al. 2006) and fungi (Utschik 2001). Nonetheless, species numbers are not a sufficient biological indicator for the ecological impacts of exotic species (Magee et al. 2010). In the studies of Utschik (2001), Leitl (2001), and Roques et al. (2006), organisms in association with Douglas fir were shown to be almost exclusively generalist and common species, which is of concern from the conservational point of view.

On the whole, the ecological consequences of Douglas fir seem to be minor. But negative consequences for single groups of organisms have been detected and are relevant for nature conservation. Although no severe impacts have been detected in the 150 years since the introduction to Europe, Douglas fir still poses a risk as a source of problems in the future. Some niches are not or only poorly occupied (Goßner et al. 2005; Auger-Rozenberg and Roques 2012; Roques et al. 2006) and accidentally introduced exotic herbivores or native insect species performing a host jump could therefore exploit such vacant niches (Roques et al. 2006) within a short time scale. Together with unexpected emerging fungal pathogens, such host jumps could cause sudden changes in the Douglas fir system with unknown ecological and economic outcomes.

Acknowledgments Many thanks to Alex Brunner, Mathias Gerber, Lioba Paul, Rita Schubert and anonymous reviewers for their helpful suggestions.We also thank J.D. Brus and his colleagues for the permission to use their distribution map of Douglas fir across Europe.

\section{References}

Albrecht A, Kohnle U, Hanewinkel M, Bauhus J (2013) Storm damage of Douglas-fir unexpectedly high compared to Norway spruce. Ann For Sci 70(2):195-207

Auger-Rozenberg M-A, Roques A (2012) Seed wasp invasions promoted by unregulated seed trade affect vegetal and animal biodiversity. Integr Zool 7(3):228-246

Augspurger CK (1984) Seedling survival of tropical tree species: interactions of dispersal distance, light-gaps, and pathogens. Ecology 65(6):1705-1712

Augusto L, Ranger J, Binkley D, Rothe A (2002) Impact of several common tree species of European temperate forests on soil fertility. Ann For Sci 59(8):233-253 
Augusto L, Dupouey J-L, Ranger J (2003) Effects of tree species on understory vegetation and environmental conditions in temperate forests. Ann For Sci 60:823-831

Avolio S, Bernardini V (2000) La parcella sperimentale no 412 di douglasia verde di Pavari nella Catena costiera calabra a settant'anni dall'impianto. Annali dell'Istituto Sperimentale per la Selvicoltura 31:119-136

Barbier S, Gosselin F, Balandier P (2008) Influence of tree species on understory vegetation diversity and mechanisms involved-a critical review for temperate and boreal forests. For Ecol Manag 254(1):1-15

Benesperi R, Giuliani C, Zanetti S, Gennai M, Lippi MM, Guidi T, Nascimbene J, Foggi B (2012) Forest plant diversity is threatened by Robinia pseudoacacia (black-locust) invasion. Biodivers Conserv 21(14):3555-3568

Bertheau C, Salle A, Rossi J-P, Bankhead-dronnet S, Pineau X, Rouxmorabito G, Lieutier F (2009) Colonisation of native and exotic conifers by indigenous bark beetles (Coleoptera: Scolytinae) in France. For Ecol Manag 258(7):1619-1628

Binkley D, Giardina C (1998) Why do tree species affect soils? The warp and woof of tree-soil interactions. Biogeochemistry 42(1): 89-106

Blaney C, Kotanen P (2001) Effects of fungal pathogens on seeds of native and exotic plants: a test using congeneric pairs. J Appl Ecol 38(5):1104-1113

Blick T, Goßner M (2006) Spinnen aus Baumkronen-Klopfproben (Arachnida: Aranea), mit Anmerkungen zu Cinetata gradata (Linyphiidae) und Theridion boesenbergi (Theridiidae). Arachnologische Mitteilungen 31:23-39

Brasier C, Webber J (2010) Sudden larch death. Nature 466(7308): $824-825$

Bringmann H-D (2001) Die nordamerikanische Douglasie (Pseudotsuga menziesii) als Entwicklungsstätte für heimische Bockkäfer (Col., Cerambycidae). Entomologische Nachrichten und Berichte 45(2):97

Brodribb TJ, Pittermann J, Coomes DA (2012) Elegance versus speed: examining the competition between conifer and angiosperm trees. Int J Plant Sci 173(6):673-694

Broncano MJ, Vila M, Boada M (2005) Evidence of Pseudotsuga menziesii naturalization in montane Mediterranean forests. For Ecol Manag 211(3):257-263

Brus D, Hengeveld G, Walvoort D, Goedhart P, Heidema A, Nabuurs G, Gunia K (2011) Statistical mapping of tree species over Europe. Eur J For Res 131(1):145-157

Budde S (2006) Auswirkungen des Douglasienanbaus auf die Bodenvegetation im nordwestdeutschen Tiefland. Faculty of Forest Sciences and Forest Ecology, Georg-August-Universität Göttingen, Cuvillier Verlag, Göttingen

Buée M, Maurice J-P, Zeller B, Andrianarisoa S, Ranger J, Courtecuisse R, Marçais B, Le Tacon F (2011) Influence of tree species on richness and diversity of epigeous fungal communities in a French temperate forest stand. Fungal Ecol $4(1): 22-31$

Bürger-Arndt R (2000) Kenntnisse zur Synökologie der Douglasie als Grundlage für eine naturschutzfachliche Einschätzung. Forst und Holz 55(22):707-712

Burmeister J, Goßner M, Gruppe A (2007) Insektengemeinschaften im Kronenraum von Koniferenarten im Forstlichen Versuchsgarten Grafrath. Nachrichtenblatt der Bayerischen Entomologen 56(1):19-28

Bušina F (2007) Natural regeneration of Douglas fir (Pseudotsuga menziesii [Mirb.] Franco) in forest stands of Hůrky Training Forest District, Higher Forestry School and Secondary Forestry School in Písek. J For Sci 53(1):20-34

Bußler H, Blaschke M (2004) Die Douglasie-(k)ein Baum für alle Fälle. LWF aktuell 46:14-15
Calvaruso C, N'Dira V, Turpault MP (2011) Impact of common European tree species and Douglas-fir (Pseudotsuga menziesii [Mirb.] Franco) on the physicochemical properties of the rhizosphere. Plant Soil 342(1):469-480

Carnus J-M, Parrotta J, Brockerhoff E, Arbez M, Jactel H, Kremer A, Lamb D, Ohara K, Walters B (2006) Planted forests and biodiversity. J For 104(2):65-77

Carrillo-Gavilán A, Espelta JM, Vilà M (2012) Establishment constraints of an alien and a native conifer in different habitats. Biol Invasions 14(6):1279-1289

Chou C-H (1993) The role of allelopathy in the diversity of plant communities in Taiwan. Botanical Bulletin of Academia Sinensis 34:211-221

Cornelissen JH, Sass-Klaassen U, Poorter L, van Geffen K, van Logtestijn RS, van Hal J, Goudzwaard L, Sterck FJ, Klaassen RK, Freschet GT (2012) Controls on coarse wood decay in temperate tree species: birth of the LOGLIFE experiment. Ambio 41(3):231-245

Davidson J, Garbelotto M, Koike S, Rizzo D (2002) First report of Phytophthora ramorum on Douglas-fir in California. Plant Dis 86(11): 1274

Deflorio G, Johnson C, Fink S, Schwarze FWMR (2008) Decay development in living sapwood of coniferous and deciduous trees inoculated with six wood decay fungi. For Ecol Manag 255(7):2373-2383

Del Moral R, Cates RG (1971) Allelopathic potential of the dominant vegetation of western Washington. Ecology 52(6): $1030-1037$

Dellus V, Mila I, Scalbert A, Menard C, Michon V, Herve du Penhoat CLM (1997) Douglas-fir polyphenols and heartwood formation. Phytochemistry 45(8):1573-1578

Dickie IA, Bolstridge N, Cooper JA, Peltzer DA (2010) Co-invasion by Pinus and its mycorrhizal fungi. New Phytol 187(2):475-484

Dodet M, Collet C (2012) When should exotic forest plantation tree species be considered as an invasive threat and how should we treat them? Biol Invasions 14(9):1765-1778

EFSA PLH (2011) Scientific Opinion on the Pest Risk Analysis on Phytophthora ramorum prepared by the FP6 project RAPRA. EFSA J 9(6):2186

Endres U, Förster B (2013) Die Douglasie in Naturwaldreservatenpasst das zusammen?. Bayerische Landesanstalt für Wald und Forstwirtschaft

Engel K (2001) Zersetzer und ihre Leistung: Buche-Fichte-Douglasie. LWF-Bericht 33:18-21

Engelmark O, Sjöberg K, Andersson B, Rosvall O, Ågren GI, Baker WL, Barklund P, Björkman C, Despain DG, Elfving B (2001) Ecological effects and management aspects of an exotic tree species: the case of lodgepole pine in Sweden. For Ecol Manag 141(1):3-13

Ennos RA (2001) The introduction of lodgepole pine as a major forest crop in Sweden: implications for host-pathogen evolution. For Ecol Manag 141(1):85-96

Essex S, Williams A (1992) Ecological effects of afforestation: a case study of Burrator, Dartmoor. Appl Geogr 12(4):361-379

Essl F (2005) Verbreitung, Status und Habitatbindung dersubspontanen Bestände der Douglasie (Pseudotsuga menzíesií) in Österreich. Phyton 45:117-144

Essl F, Mang T, Dullinger S, Moser D, Hulme PE (2011) Macroecological drivers of alien conifer naturalizations worldwide. Ecography 34(6): 1076-1084

European Commission (2013) Forests and forest related policies. European Commission. http://ec.europa.eu/environment/forests/ home_en.htm. Accessed 1 July 2013

Fagúndez J (2013) Heathlands confronting global change: drivers of biodiversity loss from past to future scenarios. Ann Bot 111(2): $151-172$ 
Farr DF, Rossman AY (2013) Fungal databases, systematic mycology and microbiology laboratory. ARS, USDA. http://nt.ars-grin. gov/fungaldatabases/. Accessed 1 July 2013

Felton A, Boberg J, Björkman C, Widenfalk O (2013) Identifying and managing the ecological risks of using introduced tree species in Sweden's production forestry. For Ecol Manag 307:165-177

Finch O-D, Szumelda A (2007) Introduction of Douglas fir (Pseudotsuga menziesii (Mirb.) Franco) into Western Europe: epigaeic arthropods in intermediate-aged pure stands in northwestern Germany. For Ecol Manag 242(2-3):260-272

Fischer A (2008) Die Eignung der Douglasie im Hinblick auf den Klimawandel. LWF Wissen 59:63-66

Fisher MC, Henk DA, Briggs CJ, Brownstein JS, Madoff LC, McCraw SL, Gurr SJ (2012) Emerging fungal threats to animal, plant and ecosystem health. Nature 484(7393):186-194

Frank D, Finckh M (1997) Impact of Douglas-fir plantations on vegetation and soil in south-central Chile. Revista Chilena de Historia Natural 70(2):191-211

Füldner K, Spork T (2003) Entwicklungserfolg von Nonne (Lymantria monacha Linnaeus, 1758: Lepidoptera, Lymantriidae) an Douglasie (Pseudotsuga menziesii), Fichte (Picea abies) und Kiefer (Pinus sylvestris) unter Laborbedingungen. Allgemeine Forst und Jagdzeitschrift 174:84-88

Ganssen R (1972) Bodengeographie-mit besonderer Berücksichtigung der Böden Mitteleuropas, 2nd edn. KF Koehler Verlag, Stuttgart

Garbelotto M, Hayden KJ (2012) Sudden Oak Death: interactions of the exotic oomycete Phytophthora ramorum with naïve North American hosts. Eukaryot Cell 11(11):1313-1323

Glatz K, Winter K, Niemeyer H (2003) Beitrag zur epigäischen Käferfauna in niedersächsischen Mischwäldern mit und ohne Douglasie. Forst und Holz 58(1/2):32-36

Goßner M (2004) Diversität und Struktur arborikoler Arthropodenzönosen fremdländischer und einheimischer Baumarten. Ein Beitrag zur Bewertung des Anbaus von Douglasie (Pseudotsuga menziesii (Mirb.) Franco) und Roteiche (Quercus rubra L.), vol 5. NEOBIOTA

Goßner M (2008) Insektenwelten-Die Douglasie im Vergleich mit der Fichte. LWF Wissen 59:70-73

Goßner M, Ammer U (2006) The effects of Douglas-fir on treespecific arthropod communities in mixed species stands with European beech and Norway spruce. Eur J For Res 125(3): 221-235

Goßner M, Bräu M (2004) Die Heteroptera der Neophyten Douglasie (Pseudotsuga menziesii) und Amerikanischer Roteiche (Quercus rubra) im Vergleich zur Fichte und Tanne bzw. Stieleiche und Buche in südbayerischen Wäldern-Schwerpunkt arborikole Zönosen. Beiträge Bayerischer Entomofaunistik 6:217-235

Goßner M, Simon U (2002) Introduced Douglas fir (Pseudotsuga menziesii (Mirb.) Franco) affects community structure of treecrown dwelling beetles in a managed European forest. In: Kowarik I, Starfinger U (eds) Biologische Invasionen-eine Herausforderung zum Handeln? vol 1. NEOBIOTA, pp 167-179

Goßner M, Utschik H (2002) Douglas fir stands deprive overwintering bird species of food resource. In: Klotz S, Kühn I (eds) Biological invasions-challenges for science, vol 3. NEOBIOTA, pp 105-121

Goßner M, Gruppe A, Simon U (2005) Aphidophagous insect communities in tree crowns of the neophyte Douglas-fir (Pseudotsuga menziesii (Mirb.) Franco) and Norway spruce (Picea abies L.). J Appl Entomol 129(2):81-88

Goßner MM, Chao A, Bailey RI, Prinzing A (2009) Native fauna on exotic trees: phylogenetic conservatism and geographic contingency in two lineages of phytophages on two lineages of trees. Am Nat 173(5):599-614
Gösswald K (1990) Die Waldameise. Bd. 2. Die Waldameise im Ökosystem Wald, ihr Nutzen und ihre Hege. Aula Verlag, Wiesbaden

Greig B, Gibbs J, Pratt J (2001) Experiments on the susceptibility of conifers to Heterobasidion annosum in Great Britain. For Pathol 31(4):219-228

Grünwald NJ, Garbelotto M, Goss EM, Heungens K, Prospero S (2012) Emergence of the sudden oak death pathogen Phytophthora ramorum. Trends Microbiol 20(3):131-138

Gruppe A, Goßner M (2006) Douglasiennadeln als Nahrungsressource für Larven von Lymantria monacha L. Ein qualitativer Vergleich mit Fichte. Mitteilungen der Deutschen Gesellschaft für allgemeine und angewandte Entomologie 15:31-35

Gugger PF, González-Rodríguez A, Rodríguez-Correa H, Sugita S, Cavender-Bares J (2011) Southward Pleistocene migration of Douglas-fir into Mexico: phylogeography, ecological niche modeling, and conservation of 'rear edge' populations. New Phytol 189(4):1185-1199

Haarstick K (1979) Erfahrungen bei der Haltung und Aufzucht von Auerwild (Tetrao urogallus L.) in der Aufzuchtstation im Staatlichen Forstamt Lonau/Harz. Zeitschrift für Jagdwissenschaft 25(3): 167-177

Hansen E, Parke J, Sutton W (2005) Susceptibility of Oregon forest trees and shrubs to Phytophthora ramorum: a comparison of artificial inoculation and natural infection. Plant Dis 89(1):63-70

Haslam E (1994) Secondary metabolism-evolution and function: products or processes? Chemoecology 5(2):89-95

Haugo RD, Bakker JD, Halpern CB (2013) Role of biotic interactions in regulating conifer invasion of grasslands. For Ecol Manag 289:175-182

Hendriks C, Bianchi F (1995) Root density and root biomass in pure and mixed forest stands of Douglas-fir and beech. NJAS Wageningen J Life Sci 43(3):321-331

Hermann RK (1982) The genus Pseudotsuga: historical records and nomenclature. Forest Research Laboratory, Special Publication 2a Oregon State University, Corvallis, USA

Hobbie SE, Reich PB, Oleksyn J, Ogdahl M, Zytkowiak R, Hale C, Karolewski P (2006) Tree species effects on decomposition and forest floor dynamics in a common garden. Ecology 87(9): 2288-2297

Hobbs RJ, Higgs E, Harris JA (2009) Novel ecosystems: implications for conservation and restoration. Trends Ecol Evol 24(11): 599-605

Höltermann A, Klingenstein F, Symank A (2008) Naturschutzfachliche Bewertung der Douglasie aus Sicht des Bundesamtes für Naturschutz (BfN). LWF Wissen 59:74-81

Horner JD, Gosz JR, Cates RG (1988) The role of carbon-based plant secondary metabolites in decomposition in terrestrial ecosystems. Am Nat 132(6):869-883

IUCN (2000) IUCN guidlines for the prevention of biodiversity loss caused by aline invasive species. In: 51st meeting of the IUCN Council, Gland Switzerland. http://cmsdata.iucn.org/downloads/ 2000_feb_prevention_of_biodiv_loss_invasive_species.pdf. Accessed 12 Dec 2012

Iverson LR, McKenzie D (2013) Tree-species range shifts in a changing climate: detecting, modeling, assisting. Landsc Ecol 28:879-889

Jansen AE (1991) The mycorrhizal status of Douglas fir in the Netherlands: its relation with stand age, regional factors, atmospheric pollutants and tree vitality. Agric Ecosyst Environ 35(2):191-208

Jonášová M, van Hees A, Prach K (2006) Rehabilitation of monotonous exotic coniferous plantations: a case study of spontaneous establishment of different tree species. Ecol Eng 28(2):141-148 
Jones CG, Lawton JH, Shachak M (1997) Positive and negative effects of organisms as physical ecosystem engineers. Ecology 78(7):1946-1957

Kaiser T, Purps J (1991) Der Anbau fremdländischer Baumarten aus der Sicht des Naturschutzes-diskutiert am Beispiel der Douglasie. Forst und Holz 46:304-305

Kirichenko N, Péré C, Baranchikov Y, Schaffner U, Kenis M (2013) Do alien plants escape from natural enemies of congeneric residents? Yes but not from all. Biol Invasions 15(9):2105-2113

Knight DH, Baker WL, Engelmark O, Nilsson C (2001) A landscape perspective on the establishment of exotic tree plantations: lodgepole pine (Pinus contorta) in Sweden. For Ecol Manag 141(1):131-142

Knoerzer D (1999) Zur Naturverjüngung der Douglasie im Schwarzwald: Inventur und Analyse von Umwelt-und Konkurrenzfaktoren sowie eine naturschutzfachliche Bewertung, vol 306. Gebrüder Borntraeger Verlagsbuchhandlung Berlin Stuttgart, Dissertationes Botanicae

Knoerzer D, Reif A (2002) Fremdländische Baumarten in deutschen Wäldern. In: Kowarik I, Starfinger U (eds) Biologische Invasionen-eine Herausforderung zum Handeln?, vol 1. NEOBIOTA, pp 27-35

Köble R, Seufert G (2001) Novel maps for forest tree species in Europe. In: Proceedings of the 8th European symposium on the physico-chemical behaviour of air pollutants: "A Changing Atmosphere!". Torino (It), 17-20 September 2001

Koch J, Thomsen I (2003) Serpula himantioides, Heterobasidion annosum and Calocera viscosa as butt rot fungi in a Danish Douglas fir stand. For Pathol 33(1):1-6

Kohlert A, Roth M (2000) Der Einfluß fremdländischer Baumarten (Douglasie: Pseudotsuga menziesii) auf saprophage Arthropoden und epigäische Regulatoren. Mitteilungen der Deutschen Gesellschaft für Allgemeine und Angewandte Entomologie 12:353-358

Kolb H (1996) Fortpflanzungsbiologie der Kohlmeise Parus major auf kleinen Flächen: Vergleich zwischen einheimischen und exotischen Baumbeständen. Journal für Ornithologie 137(2): 229-242

Konnert M, Fussi B (2012) Natürliche und künstliche Verjüngung der Douglasie in Bayern aus genetischer Sicht. Schweizerische Zeitschrift für Forstwesen 163(3):79-87

Kownatzki D, Kriebitzsch W-U, Bolte A, Liesebach H, Schmitt U, Elsasser P (2011) Zum Douglasienanbau in Deutschland. Johann-Heinrich von Thünen-Institut. Agric For Res 344:21-41

Kubartová A, Ranger J, Berthelin J, Beguiristain T (2009) Diversity and decomposing ability of saprophytic fungi from temperate forest litter. Microb Ecol 58(1):98-107

Kuiters A, Sarink H (1986) Leaching of phenolic compounds from leaf and needle litter of several deciduous and coniferous trees. Soil Biol Biochem 18(5):475-480

Laufhütte J (1997) Borkenkäfer (Scolytidae) der Douglasie (Pseudotsuga menziesii (Mirb.) Franco): Literaturrecherche und Freilanduntersuchungen. Georg-August-Universität, Göttingen

Lei PF, Scherer-Lorenzen M, Bauhus J (2012) The effect of tree species diversity on fine-root production in a young temperate forest. Oecologia 169(4):1105-1115

Leitl R (2001) Artenvielfalt und Bestandesform am Beispiel der Bodenvegetation. LWF-Bericht 33:9-13

Loo JA (2009) Ecological impacts of non-indigenous invasive fungi as forest pathogens. Biol Invasions 11(1):81-96

Magee TK, Ringold PL, Bollman MA, Ernst TL (2010) Index of alien impact: a method for evaluating potential ecological impact of alien plant species. Environ Manag 45(4):759-778

Malchair S, Carnol M (2009) Microbial biomass and C and N transformations in forest floors under European beech, sessile oak, Norway spruce and Douglas-fir at four temperate forest sites. Soil Biol Biochem 41(4):831-839
Mareschal L, Bonnaud P, Turpault M, Ranger J (2010) Impact of common European tree species on the chemical and physicochemical properties of fine earth: an unusual pattern. Eur J Soil Sci 61(1):14-23

Mareschal L, Turpault M-P, Bonnaud P, Ranger J (2013) Relationship between the weathering of clay minerals and the nitrification rate: a rapid tree species effect. Biogeochemistry 112:293-309

Metzler B (2010) Waldschutzaspekte bei Douglasie. FVA-Einblick $3: 6-8$

Meyer P (2011) Naturschutzfachliche Bewertung der Douglasie. Forstarchiv 82:157-158

Morales R, Sanfuentes E, Vives I, Molinaa E (2012) Phaeocryptopus gaeumannii, patógeno causante del "swiss needle cast" en Pseudotsuga menziesii: antecedentes de su biología, medidas de control y situación en Chile. Bosque (Valdivia) 33(2):127-134

Moslonka-Lefebvre M, Pautasso M, Jeger MJ (2009) Disease spread in small-size directed networks: epidemic threshold, correlation between links to and from nodes, and clustering. J Theor Biol 260(3):402-411

Moslonka-Lefebvre M, Finley A, Dorigatti I, Dehnen-Schmutz K, Harwood T, Jeger MJ, Xu X, Holdenrieder O, Pautasso M (2011) Networks in plant epidemiology: from genes to landscapes, countries, and continents. Phytopathology 101(4):392-403

Nordén B, Paltto H (2001) Wood-decay fungi in hazel wood: species richness correlated to stand age and dead wood features. Biol Conserv 101(1): $1-8$

OECD (2008) Consensus Document on the Biology of Douglas-Fir (Pseudotsuga Menziesii (Mirb.) Franco, vol 43. Environment, Health and Safety Publications. Series on Harmonisation of Regulatory Oversight in Biotechnology. OECD

Oh HK, Sakai T, Jones M, Longhurst W (1967) Effect of various essential oils isolated from Douglas fir needles upon sheep and deer rumen microbial activity. Appl Microbiol 15(4):777-784

Parlade J, Alvarez I, Pera J (1995) Ability of native ectomycorrhizal fungi from northern Spain to colonize Douglas-fir and other introduced conifers. Mycorrhiza 6(1):51-55

Pautasso M (2013) Phytophthora ramorum - a pathogen linking network epidemiology, landscape pathology and conservation biogeography. CAB Reviews 8:1-14

Pearse IS, Altermatt F (2013) Predicting novel trophic interactions in a non-native world. Ecol Lett 16(8):1088-1094

Peterken G (2001) Ecological effects of introduced tree species in Britain. For Ecol Manag 141(1):31-42

Pimentel D, Lach L, Zuniga R, Morrison D (2000) Environmental and economic costs of nonindigenous species in the United States. Bioscience 50(1):53-65

Pimentel D, Zuniga R, Morrison D (2005) Update on the environmental and economic costs associated with alien-invasive species in the United States. Ecol Econ 52(3):273-288

Pontégnie M, du Bus de Warnaffe G, Lebrun P (2005) Impacts of silvicultural practices on the structure of hemi-edaphic macrofauna community. Pedobiologia 49(3):199-210

Prescott CE, Grayston SJ (2013) Tree species influence on microbial communities in litter and soil: current knowledge and research needs. For Ecol Manag 309:19-27

Prietzel J, Bachmann S (2012) Changes in soil organic C and N stocks after forest transformation from Norway spruce and Scots pine into Douglas fir, Douglas fir/spruce, or European beech stands at different sites in Southern Germany. For Ecol Manag 269: 134-148

Prospero S, Vercauteren A, Heungens K, Belbahri L, Rigling D (2013) Phytophthora diversity and the population structure of Phytophthora ramorum in Swiss ornamental nurseries. Plant Pathol 62(5):1063-1071

Reyer C, Lasch P, Mohren GMJ, Sterck FJ (2010) Inter-specific competition in mixed forests of Douglas-fir (Pseudotsuga 
menziesii) and common beech (Fagus sylvatica) under climate change-a model-based analysis. Ann For Sci 67(8):805

Rice EL (1979) Allelopathy-an update. Bot Rev 45(1):15-109

Richardson DM, Rejmánek M (2004) Conifers as invasive aliens: a global survey and predictive framework. Divers Distrib 10(5-6):321-331

Ronnberg J, Vollbrecht G, Thomsen IM (1999) Incidence of butt rot in a tree species experiment in northern Denmark. Scand J For Res 14(3):234-239

Roques A, Auger-Rozenberg M-A, Boivin S (2006) A lack of native congeners may limit colonization of introduced conifers by indigenous insects in Europe. Can J For Res 36(2):299-313

Rose S, Perry D, Pilz D, Schoeneberger M (1983) Allelopathic effects of litter on the growth and colonization of mycorrhizal fungi. J Chem Ecol 9(8):1153-1162

Rożen A, Sobczyk Ł, Liszka K, Weiner J (2010) Soil faunal activity as measured by the bait-lamina test in monocultures of 14 tree species in the Siemianice common-garden experiment, Poland. Appl Soil Ecol 45(3):160-167

Russell M, Burns R, Honkala B (1990) Sylvics of North America, vol 1. US Department of Agriculture, Forest Service, Washington, DC

Schlyter P, Stjernquist I, Bärring L, Jönsson AM, Nilsson C (2006) Assessment of the impacts of climate change and weather extremes on boreal forests in northern Europe, focusing on Norway spruce. Clim Res 31(1):75-84

Schowalter TD, Hargrove W, Crossley D Jr (1986) Herbivory in forested ecosystems. Annu Rev Entomol 31(1):177-196

Schütz J, Pommerening A (2013) Can Douglas fir (Pseudotsuga menziesii (Mirb.) Franco) sustainably grow in complex forest structures? For Ecol Manag 303:175-183

Schwartz MW, Martin TG (2013) Translocation of imperiled species under changing climates. Ann N Y Acad Sci 1286:15-28

Seastedt TR, Hobbs RJ, Suding KN (2008) Management of novel ecosystems: are novel approaches required? Front Ecol Environ 6(10):547-553

Selosse MA, Jacquot D, Bouchard D, Martin F, Le Tacon F (2002) Temporal persistence and spatial distribution of an American inoculant strain of the ectomycorrhizal basidiomycete Laccaria bicolor in a French forest plantation. Mol Ecol 7(5):561-573

Skurski TC, Maxwell BD, Rew LJ (2013) Ecological tradeoffs in nonnative plant management. Biol Conserv 159:292-302

Slippers B, Stenlid J, Wingfield MJ (2005) Emerging pathogens: fungal host jumps following anthropogenic introduction. Trends Ecol Evol 20(8):420-421

Smith S, Gilbert J (2003) National inventory of woodland and trees: Great Britain. Inventory Report Great Britain. http://www. forestry.gov.uk/pdf/nigreatbritain.pdf/\$file/nigreatbritain.pdf

Steinlein T (2013) Invasive alien plants and their effects on native microbial soil communities. In: Lüttge U, Beyschlag W, Francis D, Cushman J (eds) Progress in botany, vol 74. Springer, Berlin, pp 293-319

Strong DR, Levin DA (1975) Species richness of the parasitic fungi of British trees. Proc Natl Acad Sci USA 72(6):2116-2119

Tahvanainen J, Niemelä P (1987) Biogeographical and evolutionary aspects of insect herbivory. Ann Zool Fenn 24(3):239-247

Tinnin RO, Kirkpatrick LA (1985) The allelopathic influence of broadleaf trees and shrubs on seedlings of Douglas-fir. For Sci 31(4):945-952

Turpault MP, Uterano C, Boudot JP, Ranger J (2005) Influence of mature Douglas fir roots on the solid soil phase of the rhizosphere and its solution chemistry. Plant Soil 275(1):327-336

Turpault MP, Gobran G, Bonnaud P (2007) Temporal variations of rhizosphere and bulk soil chemistry in a Douglas fir stand. Geoderma 137(3):490-496

Utschik H (2001) Schutzstrategien für Waldpilze. LWF-Bericht $33: 14-17$
Utschik H (2006) Baum- und Stratenpräferenzen nahrungssuchender Waldvogelarten in Waldbeständen unterschiedlicher Baumartenzusammensetzung. Ornithologischer Anzeiger 45(1):1-20

Vacher C, Daudin JJ, Piou D, Desprez-Loustau ML (2010) Ecological integration of alien species into a tree-parasitic fungus network. Biol Invasions 12(9):3249-3259

Van Nevel L, Mertens J, De Schrijver A, Baeten L, De Neve S, Tack FM, Meers E, Verheyen K (2013) Forest floor leachate fluxes under six different tree species on a metal contaminated site. Sci Total Environ 447:99-107

van Wilgen BW, Richardson DM (2012) Three centuries of managing introduced conifers in South Africa: Benefits, impacts, changing perceptions and conflict resolution. J Environ Manag 106:56-68

Voloscuk I (2012) Changes in forest phytodiversity caused by alien woody plants in Štiavnické vrchy Mts. Thaiszia J Bot 22:105-119

Wainhouse D, Beech-Garwood P (1994) Growth and survival of Dendroctonus micans larvae on six species of conifer. J Appl Entomol 117(1-5):393-399

Walentowski H (2008) Die Douglasie aus naturschutzfachlicher Sicht. LWF Wissen 59:67-69

Wallertz K, Malmqvist C (2013) The effect of mechanical site preparation methods on the establishment of Norway spruce (Picea abies (L.) Karst.) and Douglas fir (Pseudotsuga menziesii (Mirb.) Franco) in southern Sweden. Forestry 86(1):71-78

Walter J, Essl F, Englisch T, Kiehn M (2005) Neophytes in Austria: habitat preferences and ecological effects. Neobiota 6:13-25

Wang L, Ibrom A, Korhonen J, Arnoud Frumau K, Wu J, Pihlatie M, Schjoerring J (2013) Interactions between leaf nitrogen status and longevity in relation to $\mathrm{N}$ cycling in three contrasting European forest canopies. Biogeosciences 10(2):999-1011

Watt MS, Stone JK, Hood IA, Palmer DJ (2010) Predicting the severity of Swiss needle cast on Douglas-fir under current and future climate in New Zealand. For Ecol Manag 260(12):2232-2240

Wei X-X, Beaulieu J, Khasa DP, Vargas-Hernández J, López-Upton J, Jaquish B, Bousquet J (2011) Range-wide chloroplast and mitochondrial DNA imprints reveal multiple lineages and complex biogeographic history for Douglas-fir. Tree Genet Genomes 7(5):1025-1040

Wezel G (2008) Die Douglasie (Pseudotsuga menziesii). Anbau und Kulturbegründung. Erzeugergemeinschaft fuer Qualitätsfoerderung Süddeutschland eV 1:1-4

Winter K (2001) Zur Arthropodenfauna in niedersächsischen Douglasienforsten: I. Reinbestände in der Ostheide und im Solling. Forst und Holz 56(12):355-362

Winter K, Finch O-D, Glatz K (2001) Zur Arthropodenfauna in niedersächsischen Douglasienforsten: II. Mischbestände im Flachland. Forst und Holz 56(22):720-726

Zebisch M (2005) Klimawandel in Deutschland: Vulnerabilität und Anpassungsstrategien klimasensitiver Systeme. Clim Change 08(05):205

Zeller B, Recous S, Kunze M, Moukoumi J, Colin-Belgrand M, Bienaimé S, Ranger J, Dambrine E (2007) Influence of tree species on gross and net $\mathrm{N}$ transformations in forest soils. Ann For Sci 64(2):151-158

Zerbe S (2007) Non-indigenous plant species in Central European forest ecosystems. In: Hong SK, Nakagoshi N, Fu B, Morimoto $\mathrm{Y}$ (eds) Landscape ecological applications in man-influenced areas. Springer, Berlin, pp 235-252

Ziesche TM, Roth M (2008) Influence of environmental parameters on small-scale distribution of soil-dwelling spiders in forests: What makes the difference, tree species or microhabitat? For Ecol Manag 255(3-4):738-752

Zou J, Cates RG (1995) Foliage constituents of Douglas fir (Pseudotsuga menziesii (Mirb.) Franco (Pinaceae)): their seasonal variation and potential role in Douglas fir resistance and silviculture management. J Chem Ecol 21(4):387-402 